Article

\title{
Analysis of MC1R, MITF, TYR, TYRP1, and MLPH Genes Polymorphism in Four Rabbit Breeds with Different Coat Colors
}

\author{
Xianbo Jia (D, Peng Ding, Shiyi Chen, Shaokang Zhao, Jie Wang and Songjia Lai * \\ Farm Animal Genetic Resources Exploration and Innovation Key Laboratory of Sichuan Province, Sichuan \\ Agricultural University, Chengdu 611130, China; jaxb369@sicau.edu.cn (X.J.); m15008309752@163.com (P.D.); \\ chensysau@163.com (S.C.); z13503321824@163.com (S.Z.); wjie68@163.com (J.W.) \\ * Correspondence: laisj5794@sicau.edu.cn
}

check for updates

Citation: Jia, X.; Ding, P.; Chen, S.; Zhao, S.; Wang, J.; Lai, S. Analysis of MC1R, MITF, TYR, TYRP1, and $M L P H$ Genes Polymorphism in Four Rabbit Breeds with Different Coat Colors. Animals 2021, 11, 81. https:// doi.org/10.3390/ani11010081

Received: 11 October 2020 Accepted: 31 December 2020 Published: 5 January 2021

Publisher's Note: MDPI stays neutral with regard to jurisdictional clai$\mathrm{ms}$ in published maps and institutional affiliations.

Copyright: (C) 2021 by the authors. Licensee MDPI, Basel, Switzerland. This article is an open access article distributed under the terms and conditions of the Creative Commons Attribution (CC BY) license (https:// creativecommons.org/licenses/by/ $4.0 /)$.
Simple Summary: Coat color is an important breed characteristic and economic trait for rabbits, and it is regulated by a few genes. In this study, the gene frequencies of some pigmentation genes were investigated in four Chinese native rabbit breeds with different coat colors. A total of 14 genetic variants were detected in the gene fragments of MC1R, MITF, TYR, TYRP1, and MLPH genes, and there was low-to-moderate polymorphism in the populations. The gene frequency showed significant differences among the four rabbit populations. The above results suggest that these genetic variations play an important role in regulating the coat color of rabbits. This study will provide potential molecular markers for the breeding of coat color traits in rabbits.

Abstract: Pigmentation genes such as MC1R, MITF, TYR, TYRP1, and MLPH play a major role in rabbit coat color. To understand the genotypic profile underlying coat color in indigenous Chinese rabbit breeds, portions of the above-mentioned genes were amplified and variations in them were analyzed by DNA sequencing. Based on the analysis of 24 Tianfu black rabbits, 24 Sichuan white rabbits, 24 Sichuan gray rabbits, and 24 Fujian yellow rabbits, two indels in $M C 1 R$, three SNPs in MITF, five SNPs (single nucleotide polymorphisms) in TYR, one SNP in TYRP1, and three SNPs in $M L P H$ were discovered. These variations have low-to-moderate polymorphism, and there are significant differences in their distribution among the different breeds $(p<0.05)$. These results provide more information regarding the genetic background of these native rabbit breeds and reveal their high-quality genetic resources.

Keywords: MC1R; MITF; TYR; TYRP1; MLPH; coat color; rabbit

\section{Introduction}

Coat color is one of the important characteristics of animals. It often reflects breed characteristics, production value, species purpose value, and economic value [1,2]. The diversity of animal coat color is regulated by several genes, and the different colors are usually regulated by the major genes. These genes not only affect the change of coat color after mutation, but also control the formation of coat color through interaction [3,4]. So far, variations in 378 genes thought to be related to coat color formation in mammals have been found, of which $45 \%$ have been cloned and identified; almost half of the proteins encoded by these genes are specific or non-specific to melanosomes [5].

The melanocortin 1 receptor (MC1R) gene is mainly expressed in hair follicles and skin melanocytes and is closely related to skin pigmentation. The MC1R complex signal can activate $\alpha$ melanocyte-stimulating hormone, which leads to the production of melanin and dark brown eumelanin. Three deletion sites in the coding region of the rabbit MC1R gene (c.(124A;125_130del6), c.280_285del6, c.304_333del30) were found to be associated with white, black, red, and yellow phenotypes in rabbits [6,7]. The microphthalmia-associated 
transcription factor $(M I T F)$ gene is a key regulator in melanin synthesis; melanin participates in the proliferation, differentiation, and transport of melanocytes [8]. After MITF silencing in human melanocytes, the expression of TYR and TYRP1 protein decreased significantly at different levels, while the expression of TYRP2 protein increased significantly. Human MITF variations lead to type II Waardenburg syndrome. Patients usually have symptoms such as congenital cataracts, skin hypopigmentation, and nervous deafness [9], while affected mice show micro-ocular malformations, early-onset deafness, and hypopigmentation of fur and irises [10]. Tyrosinase (TYR) is involved in the synthesis of dopa and dopaquinone in the process of melanin synthesis [11]. The type and quantity of melanin synthesis is determined by its activity and concentration. High $T Y R$ activity and concentration lead to the production of true melanin, otherwise brown melanin is produced [12]. The variation of the rabbit TYR gene (T373K) leads to alteration of the last N-glycosylation site of the TYR coding sequence, which is significantly related to rabbit albinism [13]. The tyrosinase-related protein (TYRP1) gene is a member of the tyrosinase-related protein family and is a key factor in melanin synthesis [11]. The nonsense variation (g.41360196G> A) of rabbit TYRP1 results in the early termination codon at position 190 of the amino acid sequence (p.Trp190ter), which is significantly correlated with the brown phenotype of rabbits [14]. The melanophilin $(M L P H)$ gene is mainly involved in the transport of mature melanosomes in melanocytes and makes melanosomes gather at the dendritic ends of melanocytes. When $M L P H$ is overexpressed in melanocytes, it induces the aggregation of melanosomes to regulate animal coat color. Two variations in the coding region of the rabbit $M L P H$ gene (c.111-5C > A, c.585delG) were found to be associated with color dilution of rabbit coat color [15].

There are more than 20 indigenous and imported rabbit breeds in China, which are bred for the production of their meat, fur, and wool [16]. The production performance of Chinese indigenous rabbit breeds is generally lower than that of imported breeds, but indigenous breeds have advantages in adaptability, disease resistance, meat quality, and coat color. Unfortunately, the genetic diversity and characteristic genes of Chinese indigenous rabbits have not been well studied yet. In this study, the polymorphisms of MC1R, MITF, TYR, TYRP1, and MLPH were obtained in four Chinese native rabbit breeds by DNA sequencing to analyze the relationship between these polymorphic sites and different coat color phenotypes. It may provide a basis for the mechanism of rabbit coat color formation and provide theoretical support for rabbit coat color breeding and genetic improvement in the future.

\section{Materials and Methods}

\subsection{Ethics Statement}

Collection of biological samples and experimental procedures involved in this study were approved by the Institutional Animal Care and Use Committee at the College of Animal Science and Technology, Sichuan Agricultural University, China (No. DKYB20190103).

\subsection{Rabbit Sampling}

Ear clips from 96 adult rabbits from four Chinese rabbit breeds were collected in this study, including Tianfu black rabbit (TB, 24), Sichuan white rabbit (SW, 24), Sichuan gray rabbit (SG, 24), and Fujian yellow rabbit (FY, 24) [17]. According to pedigree records, the genetic relationships within three generations were avoided for all animals. The genomic DNA was extracted using the TIANamp Genomic DNA kit (TianGen ${ }^{\mathrm{TM}}$, Beijing, China), according to the manufacturer's instructions, and then stored at $-20{ }^{\circ} \mathrm{C}$ for later analysis.

\subsection{PCR Amplification and DNA Sequencing}

The candidate variations were selected from former publications and subjected to genotyping in the present study $[2,7,14,15,18]$. Based upon the Oryctolagus cuniculus' $M C 1 R$, MITF, TYR, TYRP1, and MLPH gene sequences (FN658678.1, NC_013677.1, NC_013669.1, NC_013669.1, and NW_003159466.1), five pairs of primer sequences (Table 1) were designed 
by the Primer Premier 5.0 software to amplify the target fragments. PCR was performed in $20 \mu \mathrm{L}$ of reaction volume, containing $50 \mathrm{ng}$ genomic DNA, $10 \mu \mathrm{M}$ of each primer, $2 \times$ MasterMix (0.05 units/mL Taq DNA polymerase, $4 \mathrm{mM} \mathrm{MgCl} 2,4 \mathrm{mM} \mathrm{dNTPs}$ ), and double-distilled (dd)H2O (Aidlab Biotechnologies Co., Ltd., China). The PCR protocol was as follows: $95{ }^{\circ} \mathrm{C}$ for $5 \mathrm{~min}, 35$ cycles of denaturing at $94{ }^{\circ} \mathrm{C}$ for $30 \mathrm{~s}$, annealing at $\mathrm{Tm}{ }^{\circ} \mathrm{C}$ (Table 1) for $30 \mathrm{~s}$, and extension at $72{ }^{\circ} \mathrm{C}$ for $30 \mathrm{~s}$, with a final extension at $72{ }^{\circ} \mathrm{C}$ for $10 \mathrm{~min}$. The products for sequencing were first electrophoresed on $1.5 \%$ agarose gels with GoldView $^{\mathrm{TM}}$ nucleic acid stain (Solarbio, China), and then purified using an Axygen ${ }^{\mathrm{TM}}$ kit (BMI Fermentas, Glen Burnie, MD, USA) and sequenced in both directions in an ABI PRIZM 377 DNA sequencer (Perkin-Elmer). The SeqMan software package was used to analyze the sequence maps.

Table 1. Information of primers used for PCR.

\begin{tabular}{cccc}
\hline Primer Names & \multicolumn{1}{c}{ Primer Sequence $\left(\mathbf{5}^{\prime} \rightarrow \mathbf{3}^{\prime}\right)$} & Fragment Size (bp) & Tm $\left.\mathbf{(}^{\circ} \mathbf{C}\right)$ \\
\hline$M C 1 R$ & $\begin{array}{l}\text { F: GCTCCCTCATGCCACC } \\
\text { R: GAACATGCGGACGTACAAAA } \\
\text { F: TGTTACTAATAGCCCTTTCC }\end{array}$ & 606 & $58{ }^{\circ} \mathrm{C}$ \\
$T Y R$ & $\begin{array}{l}\text { R: GGACACTTCTTTACCCTAG } \\
\text { F: GTGAACCAGAGGGAACAT } \\
\text { R: AAAGTGAGGTAGGCAAGG } \\
\text { F: TGCCATACCAGACCAAG } \\
\text { R: CAATGACAAACTGAGGG }\end{array}$ & 729 & $56{ }^{\circ} \mathrm{C}$ \\
$M L P H$ & $\begin{array}{l}\text { F: CCTCCCTCAGTGCCACCTCT } \\
\text { R: GGTCCCTAACTCCCACTTGG }\end{array}$ & 682 & $58{ }^{\circ} \mathrm{C}$ \\
\hline
\end{tabular}

\subsection{Statistical Analysis}

Genotype frequencies and allelic frequencies were determined by direct counting. The Hardy-Weinberg expectation was measured through a $\chi^{2}$ test. Population polymorphism information content (PIC) was calculated according to Nei's methods [19]. Difference in the genotype distribution among breeds was assessed using a Fisher's exact or chi-square test using the R language (version 3.6.1, http:/ / www.R-project.org).

\section{Results}

\subsection{SNPs of Five Gene Fragments in Four Rabbit Breeds}

A $606 \mathrm{bp}$ fragment of the MC1R gene, a $729 \mathrm{bp}$ fragment of the MITF gene, a $741 \mathrm{bp}$ fragment of the TYR gene, a $682 \mathrm{bp}$ fragment of the TYRP1 gene, and a $498 \mathrm{bp}$ fragment of the MLPH gene were amplified by PCR. MC1R, MITF, TYR, TYRP1, and MLPH gene fragments from the four rabbit breeds were of the expected sizes.

In the MC1R gene fragment, two indels (c.284-285del, c.292-295del) were found in TBs and SWs. In the MITF gene fragment, three SNPs (g.232587 A < G, g.232650C < G, g.232766A $<\mathrm{T}$ ) were found in TBs, SGs, TBs, and SWs. In the TYR gene fragment, five SNPs (c.185G < A, c.465C < T, c.498T < C, c.669C < T, c.624C < T) were found in TBs, whereas c.185G < A in SGs and c.624C < T in SWs and SGs were also observed. The TYRP1 gene fragment revealed only one SNP (g.4137286G $<$ A) in all four breeds. Three SNPs (c.693C < G, c.851A < G, c.911G < A) in fragments of the MLPH gene were only found in TBs and SWs. According to the number of SNPs in these five gene fragments, diversity was observed in the four rabbit breeds with the decreasing order of TB, SW, SG, and FY.

\subsection{Genotype Frequencies of Five Gene Fragments in Four Rabbit Breeds}

Allele and genotype frequencies were statistically analyzed for MC1R, MITF, TYR, TYRP1, and MLPH gene fragments, and the PIC values were calculated in each breed (Tables 2-6). The Fisher's exact or $\chi^{2}$ test was used to compare the genotype frequencies between different breeds. For the $M C 1 R$ gene fragment, two indels loci were found in TBs and SWs. These indels showed a low-to-moderate PIC value ranging from 0.1411 to 0.3750 
with an average of 0.2949 in the two breeds. At c.284-285del, the normal type was equal to the indel type in TBs, while the normal type was most frequent in SWs at 75.00\%. At c.292-295del, the normal type was the most frequent type in both breeds with $62.50 \%$ in TBs and $91.67 \%$ in SWs. Normal type and indel type distribution were not significantly different between the two breeds at the c.284-285del locus ( $p>0.05, \chi^{2}$ test), while the distribution of the two types were significantly different between the two breeds at the c.292-295del locus ( $p<0.05$, Fisher's exact test).

Table 2. Allelic and genotypic distribution of the $M C 1 R$ gene in four rabbit breeds.

\begin{tabular}{cccccc}
\hline Breed & Locus & \multicolumn{2}{c}{ Genotype Frequency } & PIC & $p$ Value \\
\hline & & Normal & Indel & \\
\hline TB & c.284-285del & $12(0.5000)$ & $12(0.5000)$ & 0.3750 & 0.1351 \\
SW & & $18(0.7500)$ & $6(0.2500)$ & 0.3046 & \\
\hline TB & \multirow{2}{*}{ c.292-295del } & $15(0.6250)$ & $9(0.3750)$ & 0.3589 & 0.03633 \\
SW & & $22(0.9167)$ & $2(0.0833)$ & 0.1411 & \\
\hline
\end{tabular}

Note: TB: Tianfu black rabbit; SW: Sichuan white rabbit; SG: Sichuan gray rabbit; FY: Fujian yellow rabbit; PIC: polymorphism information content. Normal is the reference genotype retrieved from NCBI.

Table 3. Allelic and genotypic distribution of the MITF gene in four rabbit breeds.

\begin{tabular}{|c|c|c|c|c|c|c|c|c|}
\hline \multirow[t]{2}{*}{ Breed } & \multirow{2}{*}{$\begin{array}{c}\text { Locus } \\
\text { g. } 232587 \mathrm{~A}<\mathrm{G}\end{array}$} & \multicolumn{2}{|c|}{ Genotype Frequency } & \multirow[b]{2}{*}{ GG } & \multicolumn{2}{|c|}{ Allele Frequency } & \multirow[t]{2}{*}{ PIC } & \multirow[t]{2}{*}{$p$ Value } \\
\hline & & AA & AG & & A & G & & \\
\hline TB & & $7(0.2917)$ & $10(0.4167)$ & $7(0.2917)$ & 0.5000 & 0.5000 & 0.3750 & 0.00349 \\
\hline \multirow[t]{2}{*}{ SG } & & $18(0.7500)$ & $2(0.0833)$ & $4(0.1667)$ & 0.7917 & 0.2083 & 0.2755 & \\
\hline & g. $232650 C<\mathrm{G}$ & $\mathrm{CC}$ & CG & GG & $\mathrm{C}$ & G & & \\
\hline \multirow[t]{2}{*}{$\mathrm{TB}$} & & $8(0.3333)$ & $8(0.3333)$ & $8(0.3333)$ & 0.5000 & 0.5000 & 0.3750 & \\
\hline & g. $232766 \mathrm{~A}<\mathrm{T}$ & AA & AT & TT & $\mathrm{A}$ & $\mathrm{T}$ & & \\
\hline SW & & $3(0.1250)$ & $4(0.1667)$ & $17(0.7083)$ & 0.2083 & 0.7917 & 0.2755 & \\
\hline
\end{tabular}

Table 4. Allelic and genotypic distribution of the $T Y R$ gene in four rabbit breeds.

\begin{tabular}{|c|c|c|c|c|c|c|c|c|}
\hline \multirow[t]{2}{*}{ Breed } & \multirow{2}{*}{$\begin{array}{c}\text { Locus } \\
\text { c. } 185 \mathrm{G}<\mathrm{A}\end{array}$} & \multicolumn{2}{|c|}{ Genotype Frequency } & \multirow[b]{2}{*}{ AA } & \multicolumn{2}{|c|}{ Allele Frequency } & \multirow[t]{2}{*}{ PIC } & \multirow[t]{2}{*}{$p$ Value } \\
\hline & & GG & GA & & G & A & & \\
\hline $\mathrm{TB}$ & & $2(0.0833)$ & $18(0.7500)$ & $4(0.1667)$ & 0.4583 & 0.5417 & 0.3733 & 0.003862 \\
\hline \multirow[t]{2}{*}{ SG } & & $0(0.000)$ & $10(0.4167)$ & $14(0.5833)$ & 0.2083 & 0.7917 & 0.2755 & \\
\hline & c. $465 \mathrm{C}<\mathrm{T}$ & $\mathrm{CC}$ & $\mathrm{CT}$ & $\mathrm{TT}$ & $\mathrm{C}$ & $\mathrm{T}$ & & \\
\hline \multirow[t]{2}{*}{ TB } & & $2(0.0833)$ & $18(0.7500)$ & $4(0.1667)$ & 0.4583 & 0.5417 & 0.3733 & \\
\hline & c. $498 \mathrm{~T}<\mathrm{C}$ & $\mathrm{TT}$ & $\mathrm{TC}$ & $\mathrm{CC}$ & $\mathrm{T}$ & $\mathrm{C}$ & & \\
\hline \multirow[t]{2}{*}{ TB } & & $2(0.0435)$ & $18(0.7826)$ & $4(0.1739)$ & 0.4583 & 0.5417 & 0.3733 & \\
\hline & c. $669 \mathrm{C}<\mathrm{T}$ & $\mathrm{CC}$ & $\mathrm{CT}$ & $\mathrm{TT}$ & $\mathrm{C}$ & $\mathrm{T}$ & & \\
\hline \multirow[t]{2}{*}{$\mathrm{TB}$} & & $4(0.1667)$ & 16(0.6667) & $4(0.1667)$ & 0.5000 & 0.5000 & 0.3750 & \\
\hline & c. $624 \mathrm{C}<\mathrm{T}$ & GG & GA & AA & G & A & & \\
\hline TB & & $2(0.0833)$ & $2(0.0833)$ & $20(0.8333)$ & 0.1250 & 0.8750 & 0.1948 & \multirow[t]{3}{*}{$\begin{array}{c}9.57 \times \\
10^{-9}\end{array}$} \\
\hline SW & & $2(0.0833)$ & $7(0.2917)$ & $15(0.6250)$ & 0.2292 & 0.7708 & 0.2909 & \\
\hline SG & & 19(0.7917) & $1(0.0417)$ & $4(0.1667)$ & 0.8125 & 0.1875 & 0.2583 & \\
\hline
\end{tabular}


Table 5. Allelic and genotypic distribution of the TYRP1 gene in four rabbit breeds.

\begin{tabular}{ccccccccc}
\hline Breed & Locus & \multicolumn{2}{c}{ Genotype Frequency } & \multicolumn{3}{c}{ Allele Frequency } & PIC & $p$ Value \\
\hline & g.4137286G $<$ A & GG & GA & AA & G & A & & \\
\hline TB & & $6(0.2500)$ & $10(0.4167)$ & $8(0.3333)$ & 0.4583 & 0.5417 & 0.3733 & 0.008868 \\
SW & & $0(0.0000)$ & $8(0.3333)$ & $16(0.6667)$ & 0.1667 & 0.8333 & 0.2392 & \\
SG & & $4(0.1667)$ & $11(0.4583)$ & $9(0.3750)$ & 0.3958 & 0.6042 & 0.3639 & \\
FY & & $0(0.0000)$ & $15(0.6250)$ & $9(0.3750)$ & 0.3125 & 0.6875 & 0.3374 & \\
\hline
\end{tabular}

Table 6. Allelic and genotypic distribution of the $M L P H$ gene in four rabbit breeds.

\begin{tabular}{ccccccccc}
\hline Breed & Locus & \multicolumn{2}{c}{ Genotype Frequency } & \multicolumn{3}{c}{ Allele Frequency } & PIC & $p$ Value \\
\hline & c.693C $<$ G & CC & CG & GG & C & G & & \\
\hline TB & & $8(0.3333)$ & $1(0.0417)$ & $15(0.6250)$ & 0.3542 & 0.6458 & 0.3528 & $6.29 \times$ \\
SW & & $6(0.2500)$ & $14(0.5833)$ & $4(0.1677)$ & 0.5417 & 0.4583 & 0.3733 & \\
\hline & & c.851A $<$ G & AA & AG & GG & A & G & \\
\hline TB & & $8(0.3333)$ & $1(0.0417)$ & $15(0.6250)$ & 0.3542 & 0.6458 & 0.3528 & 0.02236 \\
SW & & $8(0.3333)$ & $8(0.3333)$ & $8(0.3333)$ & 0.5000 & 0.5000 & 0.3750 & \\
\hline & c.911G $<$ A & GG & GA & AA & A & G & & \\
\hline TB & & $11(0.4533)$ & $0(0.0000)$ & $13(0.5417)$ & 0.4583 & 0.5417 & 0.3733 & 0.000962 \\
SW & & $8(0.3333)$ & $10(0.4167)$ & $6(0.2500)$ & 0.5417 & 0.4583 & 0.3733 & \\
\hline
\end{tabular}

For the MITF gene fragment, three SNPs were found in TBs, SGs, and SWs. These SNPs showed a moderate PIC value ranging from 0.2755 to 0.3750 with an average of 0.3253 in three breeds. At the g.232587 A < G locus, AG was the most frequent genotype in TBs with $41.67 \%$, while AA was the most frequent genotype in SGs with $75.00 \%$. Allele A was equal to $\mathrm{G}$ in TBs, whereas A was the most frequent allele in SGs with $79.17 \%$. The genotype distribution was significantly different between the two breeds $(p<0.01$, Fisher's exact test). At the g.232650 $<\mathrm{G}$ locus, the three genotypes were equal to each other in TBs. At the g.232766A $<$ T locus, genotype TT was the most frequent genotype with $70.82 \%$, and allele T was the most frequent allele in SWs with $70.83 \%$.

For the TYR gene fragment, five SNPs were found in TBs, SWs, and SGs. These SNPs showed a low-to-moderate PIC value ranging from 0.1948 to 0.3750 with an average of 0.3275 in three breeds. At the c.185G < A locus, GA was the most frequent genotype in TBs with $75.00 \%$, while AA was the most frequent genotype in SGs with $58.33 \%$. Allele A was the most frequent allele in TBs and SGs with $54.17 \%$ and $79.17 \%$, respectively. The genotype distribution was significantly different between the two breeds $(p<0.01$, Fisher's exact test). At the c.465C $<$ T locus, genotype $\mathrm{CT}$ was the most frequent genotype with $75.00 \%$, and allele $\mathrm{T}$ was the most frequent allele with $54.17 \%$ in TBs. At the c. $498 \mathrm{~T}<\mathrm{C}$ locus, genotype TC was the most frequent genotype with $78.26 \%$, and allele T was the most frequent allele with $54.17 \%$ in TBs. At the c.669C < T locus, genotype CT was the most frequent genotype with $66.67 \%$, and allele T was equal to C in TBs. At c. $624 \mathrm{C}<\mathrm{T}$, AA was the most frequent genotype in TBs and SWs with $83.33 \%$ and $62.50 \%$, respectively, while GG was the most frequent genotype in SGs with $79.17 \%$. Allele A was the most frequent allele in TBs and SWs with $87.50 \%$ and $77.08 \%$, respectively, whereas allele $\mathrm{G}$ was the most frequent allele in SGs with $81.25 \%$. The genotype distribution was significantly different between TBs and SGs $(p<0.01$, Fisher's exact test) and between SWs and SGs $(p<0.01$, Fisher's exact test).

For the TYRP1 gene fragment, only one SNP locus was found in all four breeds. The SNP showed a low-to-moderate PIC value ranging from 0.2392 to 0.3733 with an average of 0.3285 in four breeds. Genotype GA was the most frequent genotype in TBs, SGs, and FYs with $41.67 \%, 45.86 \%$, and $62.50 \%$, respectively, while AA was the most frequent genotype in SWs with $66.67 \%$. Allele A was the most frequent allele in TB, SW, SG, FY with $54.17 \%$, $83.33 \%, 60.42 \%$, and $68.75 \%$, respectively. The genotype distribution was significantly 
different between TBs and SWs ( $p<0.01$, Fisher's exact test), between TBs and FYs ( $p<0.05$, Fisher's exact test), and between SWs and SGs ( $p<0.05$, Fisher's exact test).

For the MLPH gene fragment, three SNPs were found in TBs and SWs. These SNPs showed a moderate PIC value ranging from 0.3533 to 0.3750 with an average of 0.3668 in two breeds. At the c.693C < G locus, GG was the most frequent genotype in TBs with $62.50 \%$, while CG was the most frequent genotype in SWs with $58.33 \%$. Allele G was the most frequent allele in TBs with $64.58 \%$, whereas $\mathrm{C}$ was most frequent allele in SWs with $54.17 \%$. The genotype distribution was significantly different between the two breeds $(p<0.01$, Fisher's exact test). At the c.851A $<$ G locus, GG was the most frequent genotype in TBs with $62.50 \%$, while SWs did not have a most frequent genotype. Allele $\mathrm{G}$ was the most frequent allele in TBs with $64.58 \%$, whereas allele $C$ was equal to $G$ in SWs. The genotype distribution was significantly different between the two breeds $(p<0.05$, Fisher's exact test). At the c.911G < A locus, AA was the most frequent genotype in TBs with $54.17 \%$, while AG was the most frequent genotype in SWs with $41.67 \%$. Allele $\mathrm{G}$ was the most frequent allele in TBs with $54.17 \%$, whereas A was the most frequent allele in SWs with $54.17 \%$. The genotype distribution was significantly different between the two breeds $(p<0.01$, Fisher's exact test).

\subsection{Relationship between Coat Color and MC1R, MITF, TYR, TYRP1, and MLPH Gene Polymorphisms}

There were significant effects of MC1R, MITF, TYR, TYRP, 1 and MLPH genotypes on coat color. Four SNPs may affect the black trait including c. $465 \mathrm{C}<\mathrm{T}$, c. $498 \mathrm{~T}<\mathrm{C}$, and c. $669 \mathrm{C}<\mathrm{T}$ at the TYR gene and g.232650C $<\mathrm{G}$ at the MITF gene. SNP g.232766A $<\mathrm{T}$ at the $M L P H$ gene may affect the white trait. Four variations may affect the black and white traits including c.292-295del at MC1R gene and c.693C < G, c.851A < G and c.911G < A at the $M L P H$ gene. Two SNPs may affect the black and gray traits including c.185G $<\mathrm{A}$ at the TYR gene and g.232587A $<\mathrm{G}$ at the MITF gene. SNP c.624C $<\mathrm{T}$ at the TYR gene may affect the black, white, and gray traits. SNP g.4137286G $<$ A at the TYRP1 gene may affect the black, white, gray, and yellow traits.

\section{Discussion}

Coat color is an important characteristic in rabbit breeds, and domestic animal geneticists have always paid attention to its genetic mechanism [20]. Melanin and its derivatives are the main components of tyrosine-derived pigments, and their type and quantity determine the rabbit coat color [11]. The biosynthesis of melanin is a complex process, which requires the regulation of multiple signal molecules and specific components; the $M C 1 R / c A M P$ signal pathway is one of the key components of this process. After binding to $\alpha$-MSH, MC1R induces an increase in cAMP by the action of G protein. Then, cAMP exerts its signal molecule function through PKA to upregulate MITF gene expression. MITF upregulates the expression of melanin-related genes TYR, TYRP1, and TYRP2 to catalyze the formation of melanin by L-tyrosine [5,21]. MLPH, Rab27a, and Myo5a form ternary complexes, which play a key role in the transfer of melanoma bodies from melanocytes to neighboring keratinocytes and ultimately color the animal coat $[4,22]$. Here, we investigated the variations of $M C 1 R, M I T F, T Y R, T Y R P 1$, and $M L P H$ gene fragments in 4 rabbit breeds of different colors, and found 2 indels and 12 SNPs in these 5 gene fragments. The polymorphism distribution levels of the five genes were significantly different among these four rabbit breeds. These polymorphisms may be involved in the formation of rabbit coat color.

Genetic diversity is an important basis for evaluating the status of breeding germplasm resources, and it is the genetic basis for the population's adaptation to the environment and evolution. The PIC is an important indicator reflecting the population's genetic diversity. Usually, a PIC $<0.25$ indicates low polymorphism, $0.25<$ PIC $<0.5$ indicates moderate polymorphism, and PIC $>0.5$ indicates high polymorphism [23]. For the five gene fragments in this study, moderate polymorphism was observed at all SNPs in the breeds with polymorphism, except that low polymorphism was observed at MC1R c.292- 
295del in SWs, TYRP1 g.4137286G < A in SWs and TYR c.624C < T in TBs. Moderate polymorphism was observed at 13 loci in TBs, 6 loci in SWs, 4 loci in SGs, and 1 locus in FY. Low polymorphism were observed at 1 locus in TBs and 2 loci in SWs. These results indicate that the breeding selection potential of these five genes was different in the four rabbit breeds. As a cultivated breed, the population genetic diversity of TBs is much higher than that of the other three indigenous breeds. These results are helpful to the effective exploration and conservation of the genetic resources for rabbit coat color.

The mammalian $M C 1 R$ gene is a highly polymorphic gene. Its variations are linked with the alteration of mammalian coat or skin color, such as black rats [24], chestnut horses [25], red Holsteins [26], red and white pig [27], red and black goats [28], black chickens [29], and so on. In this study, two indels (c.284-285del and c.292-295del) were found in the TB and SW breeds, and polymorphism distribution of the c.292-295del sites were significantly different between TBs and SWs $(p<0.05)$. Previous investigations found that MC1R c.280_285del6 was more frequently presented in black rabbits, c.304_333del30 was recessive red/yellow, and c.[124A;125_130del6] was connected with Japanese brindling coat color $[6,7,30]$. The MITF gene polymorphism is known to be associated with the black and white colors in mice [31], pigs [32], cattle [33], horses [34], chickens [35], ducks [36], llamas [37], and so on. In this study, three SNPs (g.232587A < G, g.232650C < G, g.232766A $<\mathrm{T}$ ) were found in the TB, SG, and SW breeds, and polymorphism distribution of the g.232587A $<\mathrm{G}$ sites were significantly different between TBs and SGs $(p<0.01)$. A previous study discovered that the mRNA expression levels of $M L P H$ in the skin of black Rex rabbits was higher than that of other Rex rabbit skin types, and it was the lowest in the skin of white Rex rabbits [2]. TYR gene variation not only affects the occurrence of human albinism, but also has a significant correlation with animal coat color, body color, and meat color. Variations in the TYR gene cause melanin deficiency in human eyes, skin, and hair, resulting in albinism [38,39]. The mRNA expression of the TYR gene was significantly different in black and white sheep [40], dark-gray and light-gray goats [41], black and white feather ducks [42], as well as black and white feather chickens [43]. Additionally, there were significant differences in dark-gray and light-gray goat black fibers and different black-bone chicken muscles [41,42]. In this study, five SNPs (c.185G < A, c.465C < T, c.498T < C, c.669C $<\mathrm{T}$, c. $624 \mathrm{C}<\mathrm{T}$ ) were found in the TB, SG, and SW breeds. Polymorphism distribution of the c.185G < A site was significantly different between TBs and SGs $(p<0.01)$, and polymorphism distribution of the c. $624 \mathrm{C}<\mathrm{T}$ site was significantly different between TBs, SWs, and SGs $(p<0.01)$. In previous studies, a TYR homozygous SNP (T373K) in albino rabbits and a $3^{\prime} U T R$ variation that targeted degradation of TYR mRNAs were identified [13]. The CRISPR/Cas9-mediated TYR knockout rabbit verified the function of these variations, which displayed albinism and graying phenotypes [18,44,45]. The TYRP1 gene is another member of the tyrosinase gene family. It is widely reported to be involved in the formation of animal coat and skin color, including in pigs [46], cattle [47], sheep [48], goats [49], and minks [50]. In this study, one SNP (g.4137286G < A) was found in the TB, SG, SW, and FY breeds, and polymorphism distribution of this site was significantly different between the four breeds $(p<0.01)$. An SNP in exon 2 of the TYRP1 gene was found in several rabbit breeds, which led to the early termination of translation of the TYRP1 gene as a strong candidate for the rabbit brown coat color locus [14]. Variations in the MLPH gene cause melanin transport defects, resulting in dilution of coat colors in cats [51], dogs [52], cattle [53], chickens [54], sheep [55], and minks [56]. In this study, three SNPs (c.693C < G, c.851A < G, c.911G < A) were found in the TB and SW breeds. Polymorphism distribution of these three sites were significantly different between TBs and SGs $(p<0.01$ or $p<0.05)$. In previous studies, two variations in the coding region of the MLPH gene, g.549853delG and c.111-5C > A, were significantly associated with rabbit coat color dilution traits $[15,57,58]$.

\section{Conclusions}

In summary, five coat color-related genes have different variation sites in four Chinese native rabbit breeds. These loci have low-to-moderate polymorphism, and there are 
significant differences in their distribution among different breeds. The results of this study will play an important role in further investigation of the molecular mechanism of the regulation of coat color phenotype of Chinese native rabbit breeds and their high-quality genetic resources.

Author Contributions: Conceptualization, S.L. and X.J.; methodology, P.D.; software, S.C.; validation, P.D. and S.Z.; formal analysis, X.J.; investigation, X.J.; resources, S.L.; data curation, P.D.; writing—original draft preparation, X.J.; writing—review and editing, J.W.; supervision, S.L.; project administration, X.J.; funding acquisition, S.L. All authors have read and agreed to the published version of the manuscript.

Funding: This research was funded by the China Agriculture Research System, grant number CARS-43-A-2 and the Sichuan science and technology support plan, grant number 2016NYZ0046).

Institutional Review Board Statement: The study was conducted according to the guidelines of the Declaration of Helsinki, and approved by the Institutional Animal Care and Use Committee at the College of Animal Science and Technology, Sichuan Agricultural University, China (No. DKYB20190103).

Informed Consent Statement: Not applicable.

Data Availability Statement: The data presented in this study are available on request from the corresponding author.

Conflicts of Interest: The authors declare no conflict of interest.

\section{References}

1. Zhang, X.; Li, W.; Liu, C.; Peng, X.; Lin, J.; He, S.; Li, X.; Han, B.; Zhang, N.; Wu, Y.; et al. Alteration of sheep coat color pattern by disruption of ASIP gene via CRISPR Cas9. Sci. Rep. 2017, 7, 8149. [CrossRef] [PubMed]

2. Hu, S.; Zhai, P.; Chen, Y.; Zhao, B.; Yang, N.; Wang, M.; Xiao, Y.; Bao, G.; Wu, X. Morphological Characterization and Gene Expression Patterns for Melanin Pigmentation in Rex Rabbit. Biochem. Genet. 2019, 57, 734-744. [CrossRef]

3. Dreger, D.L.; Hooser, B.N.; Hughes, A.M.; Ganesan, B.; Donner, J.; Anderson, H.; Holtvoigt, L.; Ekenstedt, K.J. True Colors: Commercially-acquired morphological genotypes reveal hidden allele variation among dog breeds, informing both trait ancestry and breed potential. PLoS ONE 2019, 14, 0223995. [CrossRef] [PubMed]

4. $\quad$ Bhat, B.; Singh, A.; Iqbal, Z.; Kaushik, J.K.; Rao, A.R.; Ahmad, S.M.; Bhat, H.; Ayaz, A.; Sheikh, F.D.; Kalra, S.; et al. Comparative transcriptome analysis reveals the genetic basis of coat color variation in Pashmina goat. Sci. Rep. 2019, 9, 1-9. [CrossRef] [PubMed]

5. Alshanbari, F.; Castaneda, C.; Juras, R.; Hillhouse, A.; Mendoza, M.N.; Gutierrez, G.A.; de Leon, F.A.P.; Raudsepp, T. Comparative FISH-Mapping of MC1R, ASIP, and TYRP1 in New and Old World Camelids and Association Analysis With Coat Color Phenotypes in the Dromedary (Camelus dromedarius). Front. Genet. 2019, 10, 340. [CrossRef] [PubMed]

6. Fontanesi, L.; Scotti, E.; Colombo, M.; Beretti, F.; Forestier, L.; Dall'Olio, S.; Deretz, S.; Russo, V.; Allain, D.; Oulmouden, A. A composite six bp in-frame deletion in the melanocortin 1 receptor (MC1R) gene is associated with the Japanese brindling coat colour in rabbits (Oryctolagus cuniculus). BMC Genet. 2010, 11, 59. [CrossRef]

7. Fontanesi, L.; Tazzoli, M.; Beretti, F.; Russo, V. Mutations in the melanocortin 1 receptor (MC1R) gene are associated with coat colours in the domestic rabbit (Oryctolagus cuniculus). Anim. Genet. 2006, 37, 489-493. [CrossRef]

8. Khaled, M.; Levy, C.; Fisher, D.E. Control of melanocyte differentiation by a MITF-PDE4D3 homeostatic circuit. Genes Dev. 2010, 24, 2276-2281. [CrossRef]

9. Liu, Q.; Cheng, J.; Lu, Y.; Zhou, J.; Wang, L.; Yang, C.L.; Yang, G.; Yang, H.; Cao, J.Y.; Zhang, Z.; et al. The clinical and genetic research of Waardenburg syndrome type I and II in Chinese families. Int. J. Pediatr. Otorhinolaryngol. 2020, 130, 109806. [CrossRef]

10. Reissmann, M.; Ludwig, A. Pleiotropic effects of coat colour-associated mutations in humans, mice and other mammals. Semin. Cell Dev. Biol. 2013, 24, 576-586. [CrossRef]

11. Lai, X.L.; Wichers, H.J.; Soler-Lopez, M.; Dijkstra, B.W. Structure and Function of Human Tyrosinase and Tyrosinase-Related Proteins. Chem. Eur. J. 2018, 24, 47-55. [CrossRef] [PubMed]

12. Yu, F.F.; Qu, B.L.; Lin, D.D.; Deng, Y.W.; Huang, R.L.; Zhong, Z.M. Pax3 Gene Regulated Melanin Synthesis by Tyrosinase Pathway in Pteria penguin. Int. J. Mol. Sci. 2018, 19, 3700. [CrossRef] [PubMed]

13. Song, Y.N.; Zhang, Y.X.; Chen, M.; Deng, J.C.; Sui, T.T.; Lai, L.X.; Li, Z.J. Functional validation of the albinism-associated tyrosinase T373K SNP by CRISPR/Cas9-mediated homology-directed repair (HDR) in rabbits. Ebiomedicine 2018, 36, 517-525. [CrossRef] [PubMed]

14. Utzeri, V.J.; Ribani, A.; Fontanesi, L. A premature stop codon in the TYRP1 gene is associated with brown coat colour in the European rabbit (Oryctolagus cuniculus). Anim. Genet. 2014, 45, 600-603. [CrossRef]

15. Lehner, S.; Gahle, M.; Dierks, C.; Stelter, R.; Gerber, J.; Brehm, R.; Distl, O. Two-Exon Skipping within MLPH Is Associated with Coat Color Dilution in Rabbits. PLoS ONE 2013, 8, 84525. [CrossRef] [PubMed] 
16. Long, J.R.; Qiu, X.P.; Zeng, F.T.; Tang, L.M.; Zhang, Y.P. Origin of rabbit (Oryctolagus cuniculus) in China: Evidence from mitochondrial DNA control region sequence analysis. Anim. Genet. 2003, 34, 82-87. [CrossRef]

17. Ren, A.; Du, K.; Jia, X.; Yang, R.; Wang, J.; Chen, S.Y.; Lai, S.J. Genetic diversity and population structure of four Chinese rabbit breeds. PLOS ONE 2019, 14, 0222503. [CrossRef]

18. Song, Y.N.; Xu, Y.X.; Deng, J.C.; Chen, M.; Lu, Y.; Wang, Y.; Yao, H.B.; Zhou, L.; Liu, Z.Q.; Lai, L.X.; et al. CRISPR/Cas9-mediated mutation of tyrosinase (Tyr) 3 ' UTR induce graying in rabbit. Sci. Rep. 2017, 7, 1-8. [CrossRef]

19. Nei, M.; Roychoudhury, A.K. Sampling variances of heterozygosity and genetic distance. Genetics 1974, 76, 379-390.

20. Mazouzi-Hadid, F.; Abdelli-Larbi, O.; Lebas, F.; Berchiche, M.; Bolet, G. Influence of coat colour, season and physiological status on reproduction of rabbit does in an Algerian local population. Anim. Reprod. Sci. 2014, 150, 30-34. [CrossRef]

21. Herraiz, C.; Garcia-Borron, J.C.; Jimenez-Cervantes, C.; Olivares, C. MC1R signaling. Intracellular partners and pathophysiological implications. BBA Mol. Basis Dis. 2017, 1863, 2448-2461. [CrossRef] [PubMed]

22. Li, D.H.; Wang, X.L.; Fu, Y.W.; Zhang, C.X.; Cao, Y.F.; Wang, J.; Zhang, Y.H.; Li, Y.F.; Chen, Y.; Li, Z.J.; et al. Transcriptome Analysis of the Breast Muscle of Xichuan Black-Bone Chickens Under Tyrosine Supplementation Revealed the Mechanism of Tyrosine-Induced Melanin Deposition. Front. Genet. 2019, 10, 457. [CrossRef] [PubMed]

23. Li, T.; Qu, J.Z.; Wang, Y.H.; Chang, L.G.; He, K.H.; Guo, D.W.; Zhang, X.H.; Xu, S.T.; Xue, J.Q. Genetic characterization of inbred lines from Shaan A and B groups for identifying loci associated with maize grain yield. BMC Genet. 2018, 19, 63. [CrossRef] [PubMed]

24. Benned-Jensen, T.; Mokrosinski, J.; Rosenkilde, M.M. The E92K Melanocortin 1 Receptor Mutant Induces cAMP Production and Arrestin Recruitment but Not ERK Activity Indicating Biased Constitutive Signaling. PLoS ONE 2011, 6, 24644. [CrossRef] [PubMed]

25. Shang, S.Y.; Yu, Y.; Zhao, Y.X.; Dang, W.Y.; Zhang, J.P.; Qin, X.; Irwin, D.M.; Wang, Q.; Liu, F.; Wang, Z.S.; et al. Synergy between MC1R and ASIP for coat color in horses (Equus caballus). J. Anim. Sci. 2019, 97, 1578-1585. [CrossRef]

26. Dorshorst, B.; Henegar, C.; Liao, X.P.; Almen, M.S.; Rubin, C.J.; Ito, S.; Wakamatsu, K.; Stothard, P.; Van Doormaal, B.; Plastow, G.; et al. Dominant Red Coat Color in Holstein Cattle Is Associated with a Missense Mutation in the Coatomer Protein Complex, Subunit Alpha (COPA) Gene. PLoS ONE 2015, 10, 0128969. [CrossRef]

27. Vidal, O. Deleterious mutations of MC1R in guinea pig. Anim. Genet. 2018, 49, 498-499. [CrossRef]

28. Li, J.P.; Chen, W.; Wu, S.F.; Ma, T.; Jiang, H.Z.; Zhang, Q.L. Differential expression of MC1R gene in Liaoning Cashmere goats with different coat colors. Anim. Biotechnol. 2019, 30, 273-278. [CrossRef]

29. Zhang, G.W.; Liao, Y.L.; Zhang, W.X.; Wu, Y.H.; Liu, A.F. A new dominant haplotype of MC1R gene in Chinese black plumage chicken. Anim. Genet. 2017, 48, 624. [CrossRef]

30. Xiao, N.; Li, H.L.; Shafique, L.; Zhao, S.S.; Su, X.P.; Zhang, Y.; Cui, K.Q.; Liu, Q.Y.; Shi, D.S. A Novel Pale-Yellow Coat Color of Rabbits Generated via MC1R Mutation With CRISPR/Cas9 System. Front. Genet. 2019, 10, 875. [CrossRef]

31. Chen, T.; Zhao, B.; Liu, Y.; Wang, R.; Yang, Y.; Yang, L.; Dong, C. MITF-M regulates melanogenesis in mouse melanocytes. J. Derm. Sci. 2018, 90, 253-262. [CrossRef] [PubMed]

32. Du, Y.; Ren, L.L.; Jiang, Q.Q.; Liu, X.J.; Ji, F.; Zhang, Y.; Yuan, S.L.; Wu, Z.M.; Guo, W.W.; Yang, S.M. Degeneration of saccular hair cells caused by MITF gene mutation. Neural Dev. 2019, 14, 1. [CrossRef] [PubMed]

33. Hofstetter, S.; Seefried, F.; Hafliger, I.M.; Jagannathan, V.; Leeb, T.; Drogemuller, C. A non-coding regulatory variant in the 5 '-region of the MITF gene is associated with white-spotted coat in Brown Swiss cattle. Anim. Genet. 2019, 50, 27-32. [CrossRef] [PubMed]

34. Henkel, J.; Lafayette, C.; Brooks, S.A.; Martin, K.; Patterson-Rosa, L.; Cook, D.; Jagannathan, V.; Leeb, T. Whole-genome sequencing reveals a large deletion in the MITF gene in horses with white spotted coat colour and increased risk of deafness. Anim. Genet. 2019, 50, 172-174. [CrossRef] [PubMed]

35. Wang, G.; Liao, J.; Tang, M.; Yu, S. Genetic variation in the MITF promoter affects skin colour and transcriptional activity in black-boned chickens. Br. Poult. Sci. 2018, 59, 21-27. [CrossRef] [PubMed]

36. Yang, L.; Mo, C.; Shen, W.; Du, X.; Bhuiyan, A.A.; Li, L.; Li, N.; Gong, Y.; Li, S. The recessive C locus in the MITF gene plays a key regulatory role in the plumage colour pattern of duck (Anas platyrhynchos). Br. Poult. Sci. 2019, 60, 105-108. [CrossRef] [PubMed]

37. Anello, M.; Daverio, M.S.; Silbestro, M.B.; Vidal-Rioja, L.; Di Rocco, F. Characterization and expression analysis of KIT and MITF-M genes in llamas and their relation to white coat color. Anim. Genet. 2019, 50, 143-149. [CrossRef]

38. Sun, W.; Shen, Y.J.; Shan, S.; Han, L.Y.; Li, Y.; Zhou, Z.; Zhong, Z.L.; Chen, J.J. Identification of TYR mutations in patients with oculocutaneous albinism. Mol. Med. Rep. 2018, 17, 8409-8413. [CrossRef]

39. Norman, C.S.; O'Gorman, L.; Gibson, J.; Pengelly, R.J.; Baralle, D.; Ratnayaka, J.A.; Griffiths, H.; Rose-Zerilli, M.; Ranger, M.; Bunyan, D.; et al. Identification of a functionally significant tri-allelic genotype in the Tyrosinase gene (TYR) causing hypomorphic oculocutaneous albinism (OCA1B). Sci. Rep. 2017, 7, 4415. [CrossRef]

40. Yao, L.D.; Bao, A.; Hong, W.J.; Hou, C.X.; Zhang, Z.L.; Liang, X.P.; Aniwashi, J. Transcriptome profiling analysis reveals key genes of different coat color in sheep skin. PeerJ 2019, 7, 8077. [CrossRef]

41. Chen, W.Y.; Wang, H.; Dong, B.; Dong, Z.D.; Zhou, F.N.; Fu, Y.; Zeng, Y.Q. Molecular cloning and expression analysis of tyrosinase gene in the skin of Jining gray goat (Capra hircus). Mol. Cell. Biochem. 2012, 366, 11-20. [CrossRef] [PubMed] 
42. Li, S.J.; Wang, C.; Yu, W.H.; Zhao, S.H.; Gong, Y.Z. Identification of Genes Related to White and Black Plumage Formation by RNA-Seq from White and Black Feather Bulbs in Ducks. PLoS ONE 2012, 7, 36592. [CrossRef] [PubMed]

43. Yu, S.; Wang, G.; Liao, J.; Tang, M. Five alternative splicing variants of the TYR gene and their different roles in melanogenesis in the Muchuan black-boned chicken. Br. Poult. Sci. 2019, 60, 8-14. [CrossRef] [PubMed]

44. Honda, A.; Hirose, M.; Sankai, T.; Yasmin, L.; Yuzawa, K.; Honsho, K.; Izu, H.; Iguchi, A.; Ikawa, M.; Ogura, A. Single-step generation of rabbits carrying a targeted allele of the tyrosinase gene using CRISPR/Cas9. Exp. Anim. 2015, 64, 31-37. [CrossRef] [PubMed]

45. Song, Y.N.; Yuan, L.; Wang, Y.; Chen, M.; Deng, J.C.; Lv, Q.Y.; Sui, T.T.; Li, Z.J.; Lai, L.X. Efficient dual sgRNA-directed large gene deletion in rabbit with CRISPR/Cas9 system. Cell. Mol. Life Sci. 2016, 73, 2959-2968. [CrossRef] [PubMed]

46. Wu, X.Q.; Zhang, Y.; Shen, L.Y.; Du, J.J.; Luo, J.; Liu, C.D.; Pu, Q.; Yang, R.L.; Li, X.W.; Bai, L.; et al. A 6-bp deletion in exon 8 and two mutations in introns of TYRP1 are associated with blond coat color in Liangshan pigs. Gene 2016, 578, 132-136. [CrossRef]

47. Mohanty, T.R.; Seo, K.S.; Park, K.M.; Choi, T.J.; Choe, H.S.; Baik, D.H.; Hwang, I.H. Molecular variation in pigmentation genes contributing to coat colour in native Korean Hanwoo cattle. Anim. Genet. 2008, 39, 550-553. [CrossRef]

48. Paris, J.M.; Letko, A.; Hafliger, I.M.; Ammann, P.; Flury, C.; Drogemuller, C. Identification of two TYRP1 loss-of-function alleles in Valais Red sheep. Anim. Genet. 2019, 50, 778-782. [CrossRef]

49. Becker, D.; Otto, M.; Ammann, P.; Keller, I.; Drogemuller, C.; Leeb, T. The brown coat colour of Coppernecked goats is associated with a non-synonymous variant at the TYRP1 locus on chromosome 8. Anim. Genet. 2015, 46, 50-54. [CrossRef]

50. Cirera, S.; Markakis, M.N.; Kristiansen, T.; Vissenberg, K.; Fredholm, M.; Christensen, K.; Anistoroaei, R. A large insertion in intron 2 of the TYRP1 gene associated with American Palomino phenotype in American mink. Mamm. Genome 2016, 27, 135-143. [CrossRef]

51. Ishida, Y.; David, V.A.; Eizirik, E.; Schaffer, A.A.; Neelam, B.A.; Roelke, M.E.; Hannah, S.S.; O’Brien, S.J.; Menotti-Raymond, M. A homozygous single-base deletion in MLPH causes the dilute coat color phenotype in the domestic cat. Genomics 2006, 88, 698-705. [CrossRef] [PubMed]

52. Bauer, A.; Kehl, A.; Jagannathan, V.; Leeb, T. A novel MLPH variant in dogs with coat colour dilution. Anim. Genet. 2018, 49, 94-97. [CrossRef] [PubMed]

53. Li, W.B.; Sartelet, A.; Tamma, N.; Coppieters, W.; Georges, M.; Charlier, C. Reverse genetic screen for loss-of-function mutations uncovers a frameshifting deletion in the melanophilin gene accountable for a distinctive coat color in Belgian Blue cattle. Anim. Genet. 2016, 47, 110-113. [CrossRef] [PubMed]

54. Xu, J.G.; Xie, M.G.; Zou, S.Y.; Liu, X.F.; Li, X.H.; Xie, J.F.; Zhang, X.Q. Interactions of allele E of the MC1R gene with FM and mutations in the MLPH gene cause the five-gray phenotype in the Anyi tile-like gray chicken. Genet. Mol. Res. 2016, 15. [CrossRef]

55. Posbergh, C.; Staiger, E.; Huson, H. A Stop-Gain Mutation within MLPH Is Responsible for the Lilac Dilution Observed in Jacob Sheep. Genes 2020, 11, 1. [CrossRef]

56. Cirera, S.; Markakis, M.N.; Christensen, K.; Anistoroaei, R. New insights into the melanophilin (MLPH) gene controlling coat color phenotypes in American mink. Gene 2013, 527, 48-54. [CrossRef]

57. Demars, J.; Iannuccelli, N.; Utzeri, V.J.; Auvinet, G.; Riquet, J.; Fontanesi, L.; Allain, D. New Insights into the Melanophilin (MLPH) Gene Affecting Coat Color Dilution in Rabbits. Genes 2018, 9, 430. [CrossRef]

58. Fontanesi, L.; Scotti, E.; Allain, D.; Dall'Olio, S. A frameshift mutation in the melanophilin gene causes the dilute coat colour in rabbit (Oryctolagus cuniculus) breeds. Anim. Genet. 2014, 45, 248-255. [CrossRef] 